\title{
Geotourism Potential Assessment: a Case Study of the Czech-Austrian cross-border area
}

\author{
Jiří Rypl ${ }^{1}$ (D) $\cdot$ Marek Havlíček $^{2}$ (I) $\cdot$ Ivo Dostál ${ }^{3,4}$ (I)
}

Received: 27 January 2020 / Accepted: 4 December 2020 / Published online: 6 January 2021

(C) The Author(s) 2021

\begin{abstract}
The aim of the study is to assess the potential of tourism in the Novohradské Mountains and the Gratzen Mountains on the borderland of the Czech Republic and Austria, with a focus on geotourism. A partial objective was to evaluate the accompanying infrastructure in the background of geomorphologically attractive localities, especially the accessibility of the area by means of hiking trails and accommodation facilities. Five geomorphosites in the Czech Republic and four geomorphosites in Austria were examined for characteristics and relationships. The overall density of recreational routes is much higher on the Austrian side than on the Czech territory. Similarly, the use of car traffic, cycling and hiking on the Czech side is worse than on the Austrian side. The total number of beds is currently larger on the Czech side of the territory. However, beds on the Czech side are located in smaller accommodation capacities, which experienced unprecedented development after 1989, especially with the possibility of visiting previously unavailable territory. On the Austrian side of the territory, the larger bed capacity is concentrated in hotel complexes focusing on wellness and balneology; this is mainly due to the undisturbed, long-term development of the territory and the greater purchasing power of Austrian citizens. At a distance of up to $5 \mathrm{~km}$ and within $10 \mathrm{~km}$ of the geomorphosites, there are significantly larger accommodation capacities on the Czech side of the territory. In a wider area within $15 \mathrm{~km}$, the accommodation capacities in both territories are similar. This is due to the location of geomorphosites in Austria, which are located in more central and interesting parts of the mountainous area, far from settlements. The availability of accommodation facilities in the wider area combined with other attractions has great potential for multi-day stays in the region.
\end{abstract}

Keywords Geomorphosites · Tourist potential · Recreational trails · Accommodation · The Novohradské Mountains · The Gratzen Mountains

Jiří Rypl

rypl@pf.jcu.cz

Marek Havlíček

marek.havlicek@vukoz.cz

Ivo Dostál

ivo.dostal@cdv.cz

1 Department of Geography, Faculty of Education, University of South Bohemia, České Budějovice, Czech Republic

2 Silva Tarouca Research Institute for Landscape and Ornamental Gardening, Brno, Czech Republic

3 Transport Research Centre (CDV), Brno, Czech Republic

4 Department of Ecology and Environmental Science, Faculty of Natural Sciences, Constantine the Philosopher University, Nitra, Slovakia

\section{Introduction}

Tourism takes people away from their familiar surroundings to experience a different world for leisure or education (e.g. Fleetwood 1995 in Evans et al. 2018). This is usually through travel, with the main focus being the novelty of the places visited. Increasingly however, specialist forms of tourism are being developed for more experienced travellers, for whom visiting new places is no longer enough of a novelty (Evans et al. 2018). Visits based around archaeology (archatourism) or wildlife (ecotourism) have become well-established (Honey 2008; Al Busaidi 2010), and now landscape and geology (geodiversity) are increasingly used to enhance the visitor experience - known as geotourism (e.g. Hose 2005, 2008 in Evans et al. 2018).

According to Dowling (2011), geotourism is defined as a form of nature tourism that specifically focuses on landscape and geology, and these components are an important part of 
geodiversity (Gray 2013). Geotourism promotes tourism to geosites and the conservation of geodiversity and an understanding of Earth sciences through appreciation and learning (Dowling and Newsome 2018; Kubalíková 2018). It is clear that not only geological but also geomorphological features and processes are considered a resource for geotourism (Kubalíková 2013).

Reynard et al. (2003) analysed the relationships between geomorphology and tourism. Geomorphology may be a tourist resource as part of the primary or original offering(e.g. a geomorphological site as an attraction or as support for tourist activities such as climbing),or a secondary or derived offering, when tourist infrastructures (e.g. educational trails), instruments (e.g. educational booklets) or services (e.g. guided tours) are proposed for effective use of the original offer. Gray (2004) also pointed out that geodiversity and geoheritage are of great value for geotouristic and geoeducational activities.

Evaluations of tourism potential in relation to geotourism are based not only on the importance and attractiveness of geomorphological and geological sites (Kubalíková 2013; Bajer et al. 2014; Kim et al. 2019) but also on the availability of these sites by cycling, hiking, car and public transport (Bajer et al. 2018).

A sufficient number of accommodation facilities near geomorphosites (Bajer et al. 2018; Honțuş et al. 2015) is also of great importance. Accommodation facilities in naturally protected areas should preferably be built in accordance with nature and landscape conservation conditions with minimal impacts on the most valuable areas (Widawski et al. 2018). A lack of accommodation can be a constraint on the tourist development of the area or may be a limitation for longer stays in the region (Vijulie et al. 2018). Another issue is the concentration of tourist at the most attractive tourist destinations and routes in protected areas (Kim et al. 2019; Widawski et al. 2018). Building thematic nature trails and alternative hiking trails (Widawski et al. 2018) are good solutions to achieve a more balanced tourist burden.

In this paper, we report on the area of the Novohradské Mountains and the Gratzen Mountains on the borderland of the Czech Republic and Austria. This area was part of the Iron Curtain before 1989. The area offers potential for the development of geotourism, primarily for its preserved rocky landforms (e.g. Rypl et al. 2014, 2016; Rypl and Kirchner 2017; Migoń et al. 2018) and for its geosite viewpoints (Migoń and Migoń 2017).

\section{Aim of the Study}

The aim of the study is to assess the potential of tourism in the Novohradské Mountains and the Gratzen Mountains on the borderland of the Czech Republic and Austria with a focus on geotourism. A partial objective was to evaluate the accompanying infrastructure in the background of geomorphologically attractive localities, especially the accessibility of the area by means of hiking trails and accommodation facilities. Based on the spatial analyses, the availability of geomorphosites in the Czech and Austrian territories was also compared with existing border area tourism in the region, and the possibility of longer tourist stays in the region was evaluated. According to the administrative division, the Novohradské Mountains belong to the South Bohemian Region and the Gratzen Mountains to the federal state of Upper Austria.

\section{Materials and Methods}

\section{Selection and Characteristics of Geomorphological Localities}

For evaluating the tourist potential in the study area with a focus on geotourism, the most geomorphologically attractive localities on the Czech and Austrian territory were evaluated. The selection was based on information from available maps, thematic geological and geomorphological maps, tourist maps, the availability of documentation on protected areas and geological territories of the region, and on the basis of field research (e.g. Chábera and Huber 1999; Huber 1999; Rypl et al. 2017, 2020). Localities on the Czech side included Mt. Kamenec, Mt. Myslivna, Mt. Vysoká, Mt. Kraví hora and Mt. Kuní hora and on the Austria side Mt. Mandelstein, Mt. Nebelstein, Mt. Warzenstein and Mt. Eichelberg. These are attractive locations with significant geomorphological shapes (tors, castle koppies, frost-riven cliffs, weathering pits, mushroom's rocks, etc.).

Each significant geomorphological locality was entered into geographic information systems (GIS) and was described by fundamental characteristics - altitude, rock composition, predominant formations, etc. Localization in GIS was then used for partial spatial analyses in relation to tourist routes and accommodation capacities.

\section{Network for General Accessibility of Territory}

Spatial road data from Open Street Map were used to create a network model in GIS. Each road was classified as an OSM road category defined according to Ramm (2017) and rated in terms of usability for one of the three basic types of transportation (car, bike and walk) (Table 1). The advantage of this approach is the unified methodology for both sides of the border. The resulting network was checked against actual orthophotomaps, and field survey was also used in unclear cases.

Since the availability of regular and reliable connections by train and bus is important in terms of the sustainable tourism, 
Table 1 OSM road categories and their usability for types of transportation

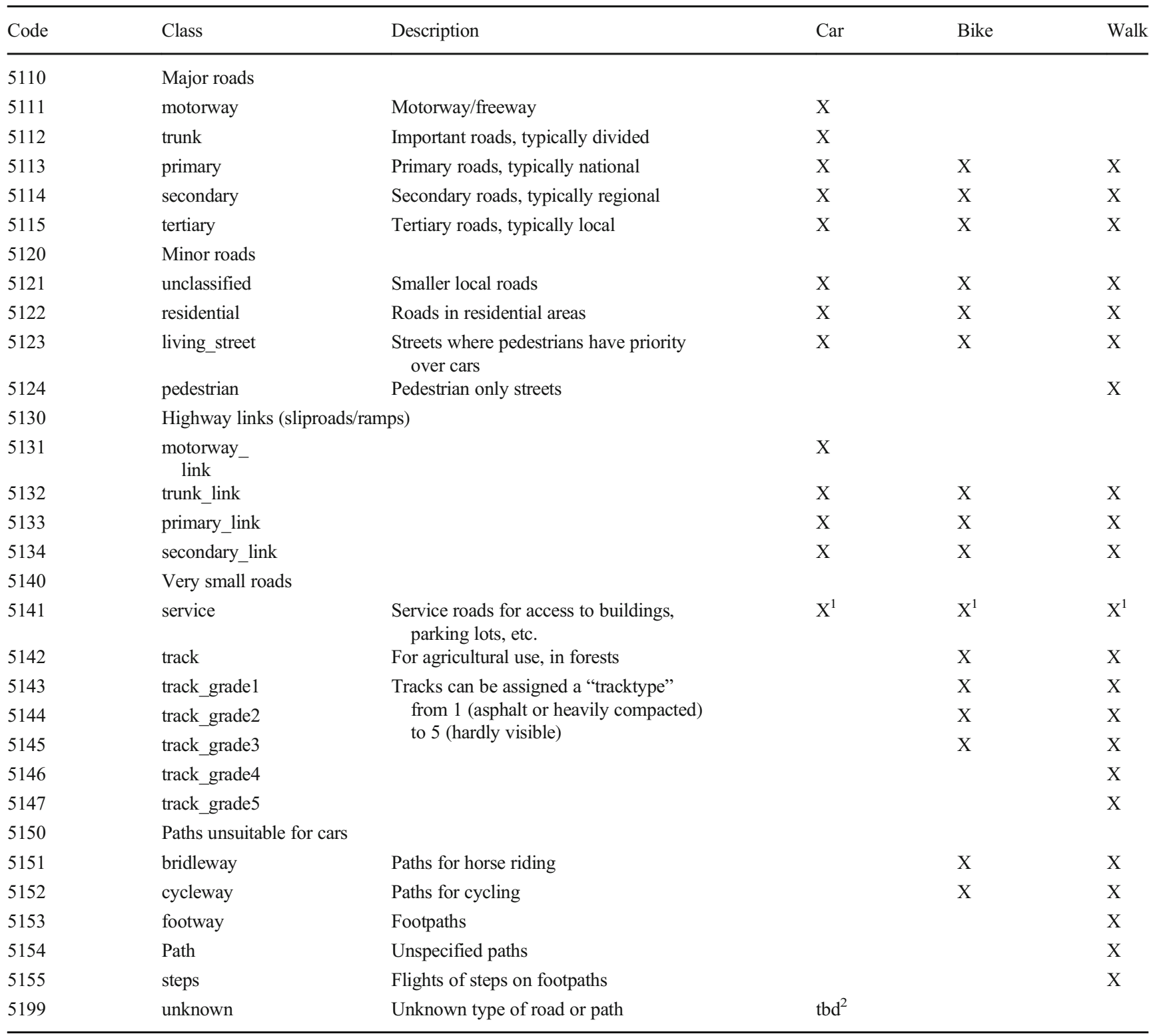

${ }^{1}$ Where applicable

${ }^{2}$ To be determined manually

the location and serviceability of public transport (PT) stops were also mapped. Timetables from idos.cz and vor.at were used to determine the number of connections for each stop. The basic rule for PT service was that stops should have at least three connections during workdays and a minimum of two connections on each weekend day.

\section{Mapping of Marked Recreational Trails}

As an extension to the network for general accessibility, a network of recreational trails was also mapped. In general, the network in the Czech Republic is managed by KČT (the Czech Tourist Club); however, local stakeholders such as municipalities, local NGOs and regional partnership groups also create local and special tourist routes. The Czech Republic has a long tradition of maintaining hiking routes, and a sophisticated marking system exists throughout the country. Maps of KČT plus the internet resources mapy.cz, novohradsko.cz and the Austrian https://www.bergfex.com were used to identify the trails. All types of marked trails for recreational use in the study area were mapped in the GIS. These trails can be classified into basic categories: 
- Hiking - tourist marked trails, paths for handicapped people

- Cycling - cycling trails and marked cycling routes including MTB trails

- Nature educational trails

Winter trails for cross-country skiing were not included in the mapping because of the presumed limited impact on the potential of geo-educational activities.

An analytic indicator of the "density of marked recreational trails in the area" (Bajer et al. 2014) was calculated for the whole area to evaluate the accessibility of each part of the study area. For this purpose, the spatial analysis "line density" in ArcGIS was performed with the a raster cell size of $25 \mathrm{~m}$, and circular search of surrounding lines of $1780 \mathrm{~m}$ (corresponds to an area of $10 \mathrm{~km}^{2}$ ). The output value was the overall trail density in $\mathrm{km}$ per square $\mathrm{km}$.

\section{Accommodation Capacities in the Territory}

Accommodation capacities near important geomorphological sites were investigated at a maximum distance of $15 \mathrm{~km}$. This distance is still considered sufficient close to allow visiting the locality during an overnight tourist stay (Bajer et al. 2014). At the same time, the availability of geomorphological sites from accommodation facilities was investigated by zone (Bajer et al. 2018), using areas within $5 \mathrm{~km}$ (accessible by hiking), up to $10 \mathrm{~km}$ (accessible by hiking or cycling), up to $15 \mathrm{~km}$ (accessible by cycling or partially by car).

Data of collective accommodation establishments (CAE) in the Czech Republic were obtained from Accommodation Establishment Register (Czech Statistical Office 2019), which is continually updated based on available information sources, and includes the capacity and occupancy rate of the CAEs. A spatial database of CAEs was then created in GIS using the addresses and names of individual CAEs. The specific capacities of all accommodation facilities were verified using the websites of individual facilities, available information from international (e.g. Booking.com) and Czech (e.g. www. dopenzionu.cz) accommodation servers, the map applications Mapy.cz and Google Maps and municipal websites in the area of interest. All accommodation facilities were entered in the GIS using the WGS84 coordinate system, allowing spatial analyses to be performed in relation to significant geomorphosites.

\section{Study Area}

The studied area is the geomorphological unit of the Novohradské Mountains on the Czech side and the Gratzen Mountains on the Austria side (see Fig. 1). According to the geomorphological classification of the Czech Republic, the
Novohradské Mountains unit belongs to the Šumava System (Balatka and Kalvoda 2006; Demek and Mackovčin (eds.) 2006). According to the geomorphological classification of Austria, the Gratzen Mountains are part of the "Granit- und Gneis-Hochland" (Weber and Duyster 1990).

From a geological point of view, the study area stretches across the southern part of the Moldanubian Pluton (Pavlíček 2004: Weber and Duyster 1990). Late Variscan magmatites of this magmatic body predominate within the study area. Several types are present (e.g. the Weinsberg type granite, the Mrákotín type granite), and they are partly covered with cordierite gneisses and nebulitic migmatites, which are the remnants of the original pluton mantle (Heřmánek and Matějka 1998). The oldest geological unit of the territory is the Moldanubicum crystalline basement, dominated by heavily metamorphosed gneisses and migmatites, sometimes with numerous inserts of quartzite, marble, amphibolite, orthogneiss and other material (Cháb et al. 2008).

The basic relief of the study area has characteristic elements of a fault-block mountain range with delimitations marked strongly by erosion, but also with clearly polygenetic elements. It is possible to find recent forms (rounded blocks of different sizes, alcoves, grooves), as well as fossil forms like exfoliation joints, tors and frost-riven cliffs (e.g. Demek et al. 2014; Huber 1999; Chábera and Huber 1999; Rypl and Kirchner 2017).

The study area in the transitional climatic zone of the Central European type, influenced by a mountainous climate with reduced summer/winter temperature variation, increased cloud cover and precipitation, and a higher number of sunny days in autumn and winter seasons. Altitude and land relief segmentation are important factors, with considerably decreasing temperatures and increasing precipitation as the altitude increases (Tolasz and Baštýřová 2007).

The territory of the Novohradské Mountains belongs to the North Sea drainage area and the Vltava river catchment, while the territory of the Gratzen Mountains belongs to the Black Sea area and the Danube river catchment. Since the Czech rivers Lužnice, Stropnice, Černá and Malše have their sources in Austria, their respective catchments extend into that country as well.

The basic soil types in the study area are cambisols, cryptopodzols and podzols, gleyish cambisols and pseudogleys, gleys and organosols (the nomenclature system by Němeček et al. 2001), with the most important being cambisols and cryptopodzols. Cambisols are among the most common soil types in the mountain range. They are formed from slope sediments of all solid rocks, mainly in the areas with rather large slopes. Cryptopodzols dominate the peak areas displaying different subtypes of poorly developed soils (Šefrna 2004).

In a broader sense, the described area is biogeographically part of the Euro-Siberian subregion of the Holarctis. In terms 
Fig. 1 Localisation of the study area

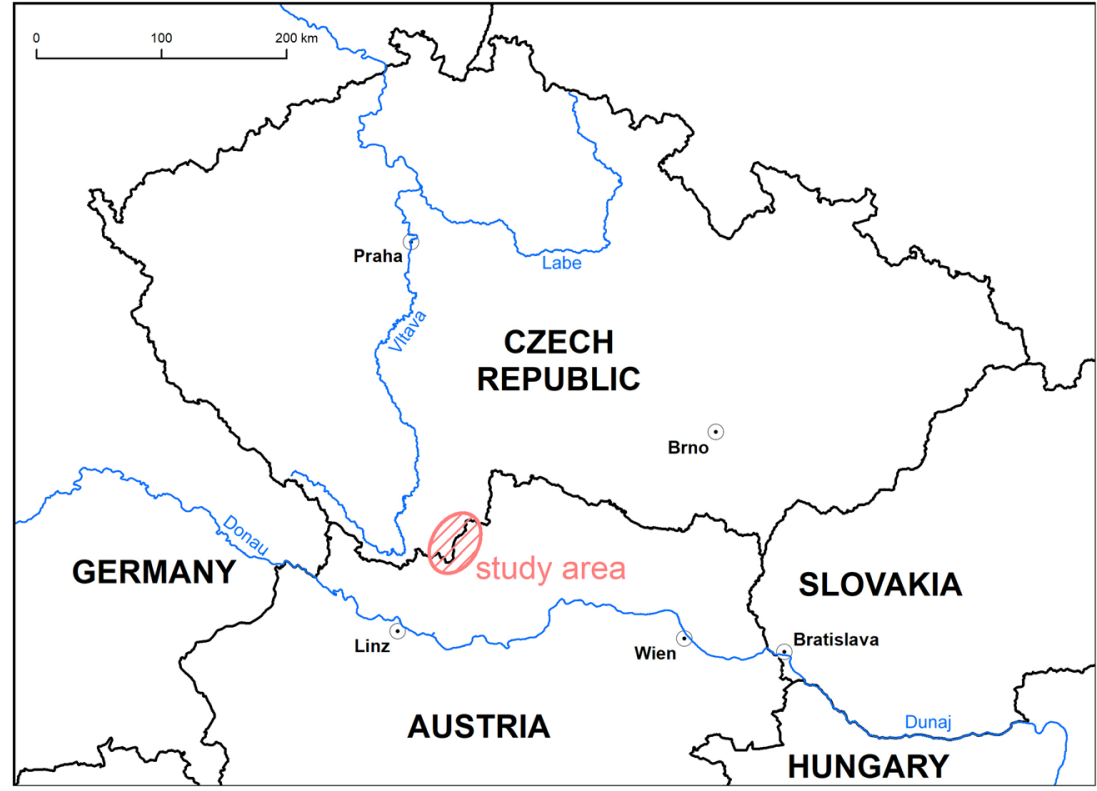

of Europe, the territory is part of the biogeographical province of Central European deciduous forests and the Hercynian biogeographical sub-province (Culek 1996). The biota in the study area is typical of the fir-beech vegetation zone, accompanied by biota of the beech vegetation zone at lower elevations and biota of the spruce-fir-beech vegetation zone at higher elevations. The zonal spruce woods vegetation zone is not represented due to the relatively low elevation of this mountain range (Culek 1996).

Climatic zones, soil types and biogeography are related to the current development of rock landforms preserved on individual geomorphosites. Thanks to the current physical-geographical conditions, significant rock landforms are preserved, such as tors, castle koppies and frost-riven cliffs and these rock landforms are indicators of past environments (Michniewicz 2019).

The whole area of the Novohradské Mountains on the Czech side is protected as a "Natural Park", though in 2005, the Czech Government officially refused to declare the area as "Protected landscape area" (Rypl et al. 2019). There are also some naturally protected areas in the Gratzen Mountains, but with smaller area, e.g. the "Natural Park" Naturpark Nordwald Großpertholz with an area of 526 ha-see (Naturpark Nordwald Grosspertholz, 2019; https://www.naturparke.at/naturparke/ niederoesterreich/naturpark-nordwald-grosspertholz/).

Sites within the framework of the Natura 2000 see (Natura 2000 Network Viewer, 2019; http://natura2000. eea.europa.eu/) international protection program are present in both countries, with 9051 ha in the Czech Republic the Novohradské Mountains and 54,081 ha in the Austria the Gratzen Mountains. There are also several Habitats Directive Sites (proposed SCIs (pSCIs), Sites of Community Importance (SCIs) and Special Areas of Conservations (SACs)) on both sides of the territory, some of which include geomorphologically interesting sites-see (Natura 2000 Network Viewer, 2019; http://natura2000.eea.europa. $\mathrm{eu} /$ ). Additionally, in the Novohradské Mountains, there are two older and smaller specially protected areas, the National Nature Reserve Žofin Natural Forest (1838) and the National Natural Monument Hojná Voda (1838).

A description of individual localities (see Fig. 2) selected for assessments of tourist potential is given below:

\section{Mt. Kamenec:}

Location: $3.5 \mathrm{~km}$ southwest of the Pohoří na Šumavě village

Altitude: $1072 \mathrm{~m}$ a. s. 1.

Bedrock: magmatites of the Central Moldanubian Pluton medium grained, porphyritic Weinsberg granites

The top of Mt. Kamenec is formed by a group of seven tors and by a castle koppie

\section{Mt. Myslivna}

Location: $3.5 \mathrm{~km}$ northwest of the Pohoří na Šumavě village

Altitude: $1040 \mathrm{~m}$ a. s. 1.

Bedrock: magmatites of the Central Moldanubian Pluton medium grained, porphyritic Weinsberg granites

The top of Mt. Myslivna is formed by two castle koppies and a rock torso

Mt. Vysoká

Location: $1.8 \mathrm{~km}$ southeast of the Hojná Voda village

Altitude: $1034 \mathrm{~m}$ a. s. 1.

Bedrock: magmatites of the Central Moldanubian Pluton medium grained, porphyritic Weinsberg granites

The top of Mt. Vysoká is formed by two well-developed castle koppies and by a massive tor

Mt. Kraví hora

Location: $0.5 \mathrm{~km}$ west of the Hojná Voda village 
Fig. 2 Selected geomorphosites in the study area

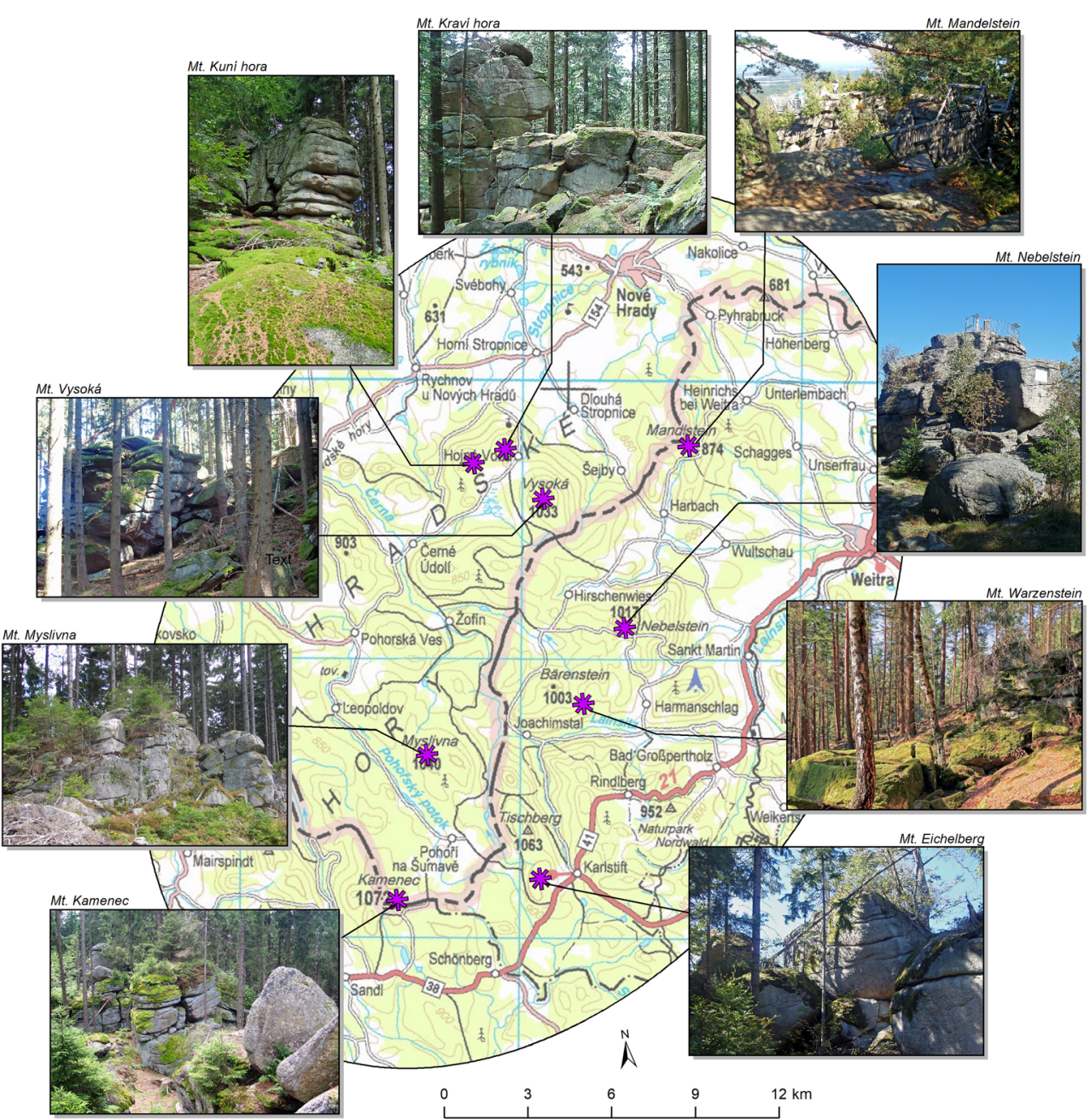

Altitude: 953 m a. s. 1.

Bedrock: magmatites of the Central Moldanubian Pluton medium grained, porphyritic Weinsberg granites

The top of Kraví hora is formed by a castle koppie and a conspicuous mushroom's rock called Napoleon's head

\section{Mt. Kuni hora}

Location: $1.5 \mathrm{~km}$ southwest of the Hojná Voda village

Altitude: $925 \mathrm{~m}$ a. s. 1 .
Bedrock: magmatites of the Central Moldanubian Pluton medium grained, porphyritic Weinsberg granites

The top of Mt. Kuní hora is formed by two smaller tors and a castle koppie

\section{Mt. Mandelstein}

Location: $2.1 \mathrm{~km}$ southwest of the Heinrichs bei Weitra village

Altitude: $874 \mathrm{~m}$ a. s. 1.

Table 2 Accessibility of the geomorphosites in the study area

\begin{tabular}{|c|c|c|c|c|c|c|c|c|c|}
\hline Accessibility from & $\begin{array}{l}\text { Mt. } \\
\text { Kamenec }\end{array}$ & $\begin{array}{l}\text { Mt. } \\
\text { Myslivna }\end{array}$ & $\begin{array}{l}\text { Mt. } \\
\text { Vysoká }\end{array}$ & $\begin{array}{l}\text { Mt. Kuní } \\
\text { hora }\end{array}$ & $\begin{array}{l}\text { Mt. Kraví } \\
\text { hora }\end{array}$ & $\begin{array}{l}\text { Mt. } \\
\text { Mandelstein }\end{array}$ & $\begin{array}{l}\text { Mt. } \\
\text { Nebelstein }\end{array}$ & $\begin{array}{l}\text { Mt. } \\
\text { Warzenstein }\end{array}$ & $\begin{array}{l}\text { Mt. } \\
\text { Eichelberg }\end{array}$ \\
\hline Nearest PT stop by walk [km] & 4.5 & 5.4 & 2.7 & 2.0 & 1.2 & 4.5 & 1.9 & 4.0 & 1.5 \\
\hline $\begin{array}{l}\text { Nearest PT stop with weekend service } \\
\text { by walk }[\mathrm{km}]\end{array}$ & 4.5 & 15.7 & 2.7 & 2.0 & 1.2 & 8.5 & 6.4 & 7.6 & 1.5 \\
\hline Nearest marked trail by walk $[\mathrm{km}]$ & 0.0 & 4.3 & 0.0 & 0.1 & 0.0 & 0.0 & 0.0 & 0.0 & 0.7 \\
\hline Nearest bike trail by bike $[\mathrm{km}]$ & $\mathrm{n} / \mathrm{a}$ & 3.3 & 1.6 & $\mathrm{n} / \mathrm{a}$ & 1.9 & $\mathrm{n} / \mathrm{a}$ & 0.5 & 1.8 & $\mathrm{n} / \mathrm{a}$ \\
\hline $\begin{array}{l}\text { Nearest parking lot for cars by walk } \\
{[\mathrm{km}]}\end{array}$ & 3.2 & 2.5 & 1.9 & 1.7 & 0.7 & 0.6 & 0.5 & 2.4 & 0.8 \\
\hline Trail density $[\mathrm{km} / \mathrm{sq} \mathrm{km}]$ & 0.829 & 0.154 & 1.047 & 1.458 & 1.700 & 1.421 & 2.457 & 0.978 & 0.941 \\
\hline
\end{tabular}




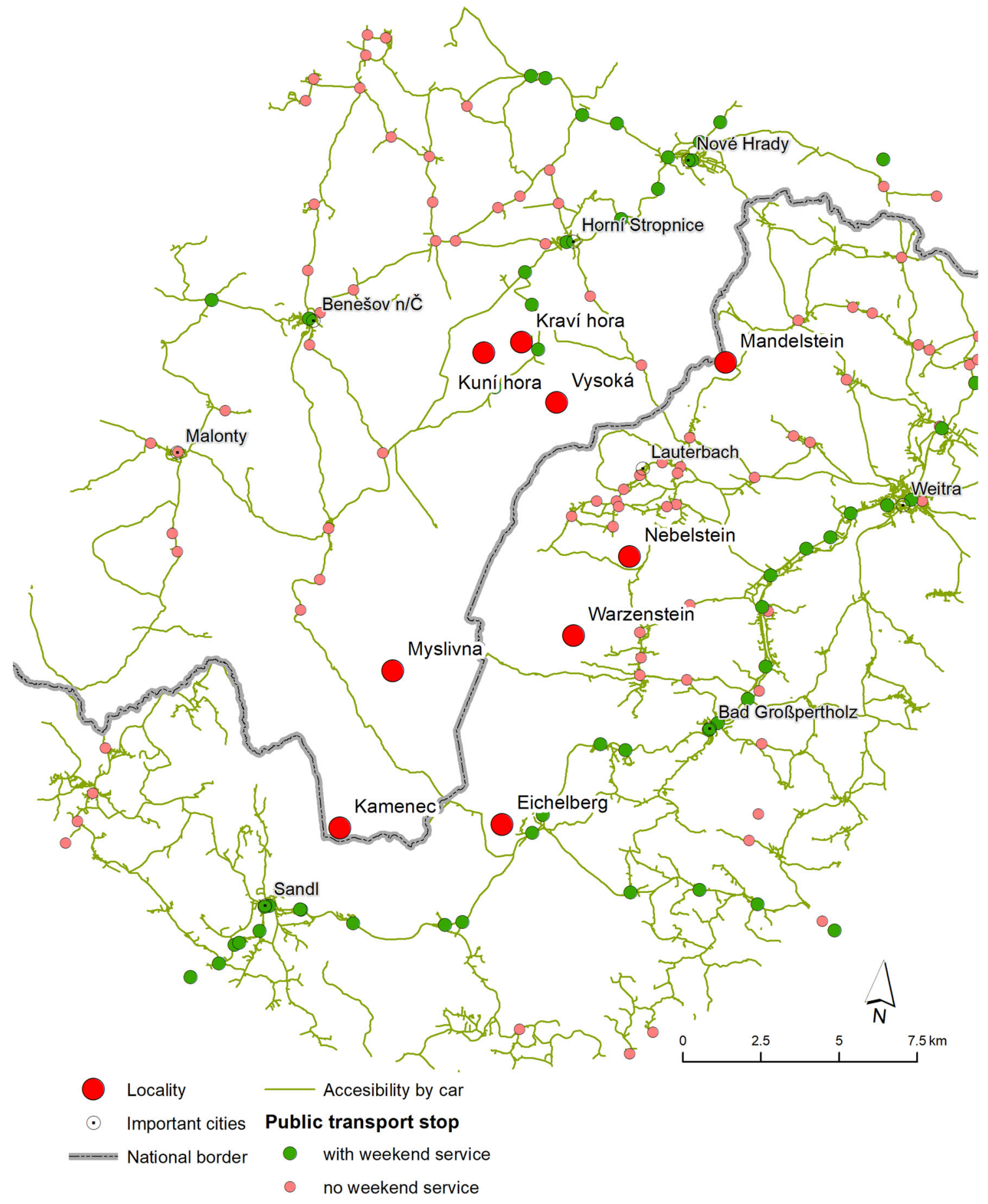

Fig. 3 Accessibility by car and public transport

Bedrock: magmatites of the Central Moldanubian Pluton medium grained, porphyritic Weinsberg granites

The top of Mandelstein is formed by a castle koppie with a viewing area and can thus be classified as a viewpoint geosite (Migoń and Migoń 2017).

\section{Mt. Nebelstein}

Location: $2.4 \mathrm{~km}$ northwest of the Harmanschlag village Altitude: $1017 \mathrm{~m}$ a. s. 1.
Bedrock: magmatites of the Central Moldanubian Pluton medium grained, porphyritic Weinsberg granites

The top of Nebelstein is formed by a castle koppie with a viewing area and can thus be classified as a viewpoint geosite (Migoń and Migoń 2017).

Mt. Warzenstein

Location: $1.7 \mathrm{~km}$ west of the Harmanschlag village Altitude: $860 \mathrm{~m}$ a. s. 1. 


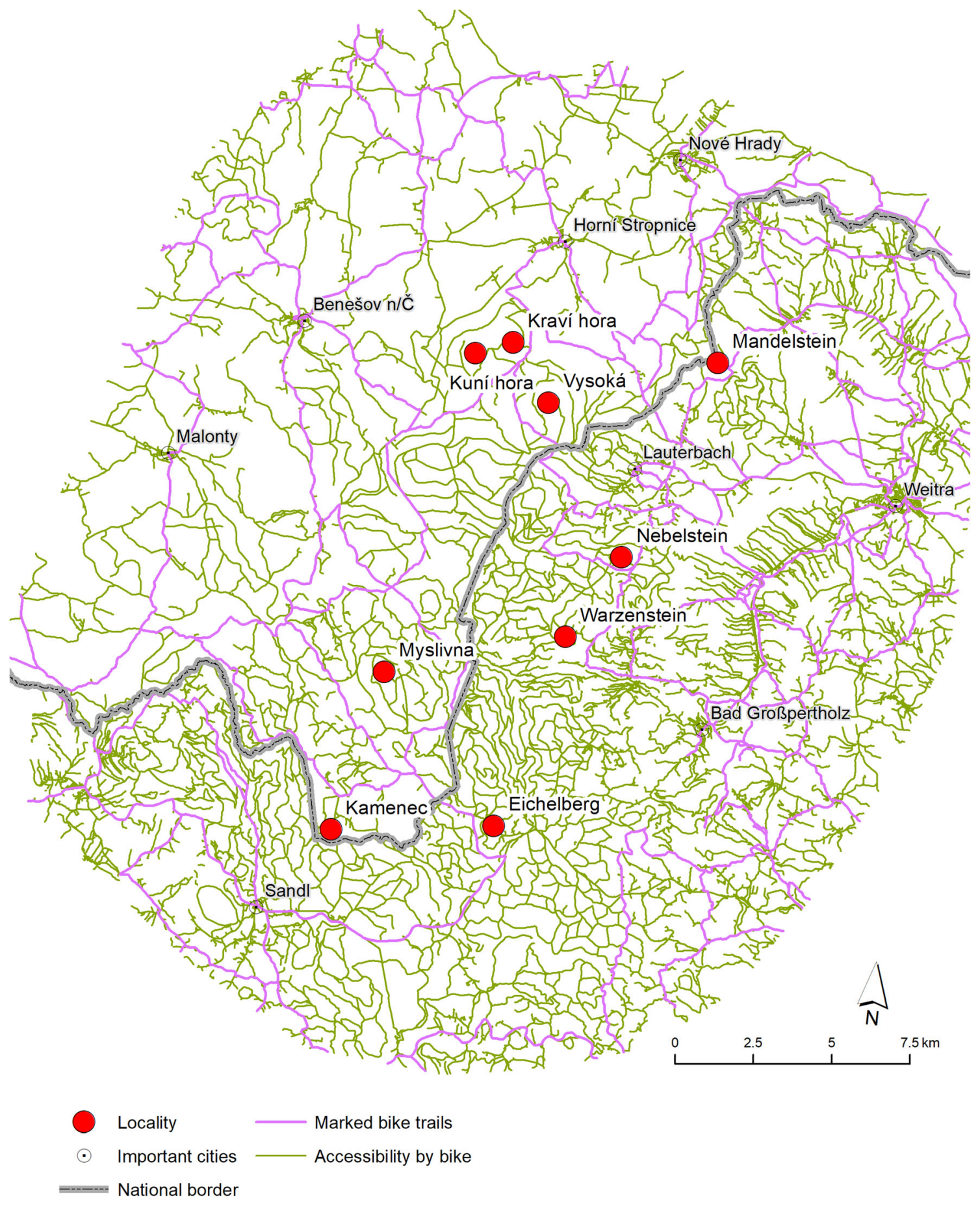

Fig. 4 Accessibility by bike and marked bike trails

Bedrock: magmatites of the Central Moldanubian Pluton medium grained, porphyritic Weinsberg granites

Warzenstein is formed by a castle koppie and by an extensive weathering pit

Mt. Eichelberg

Location: $1.0 \mathrm{~km}$ west of the Karlstift village

Altitude: $1054 \mathrm{~m}$ a. s. 1 .

Bedrock: magmatites of the Central Moldanubian Pluton medium grained, porphyritic Weinsberg granites
The top of Eichelberg is formed by a castle koppie

\section{Results}

\section{Transport Facilities}

On the Czech side, the Novohradské Mountains do not yet have such a well-developed network of hiking marked trails as 


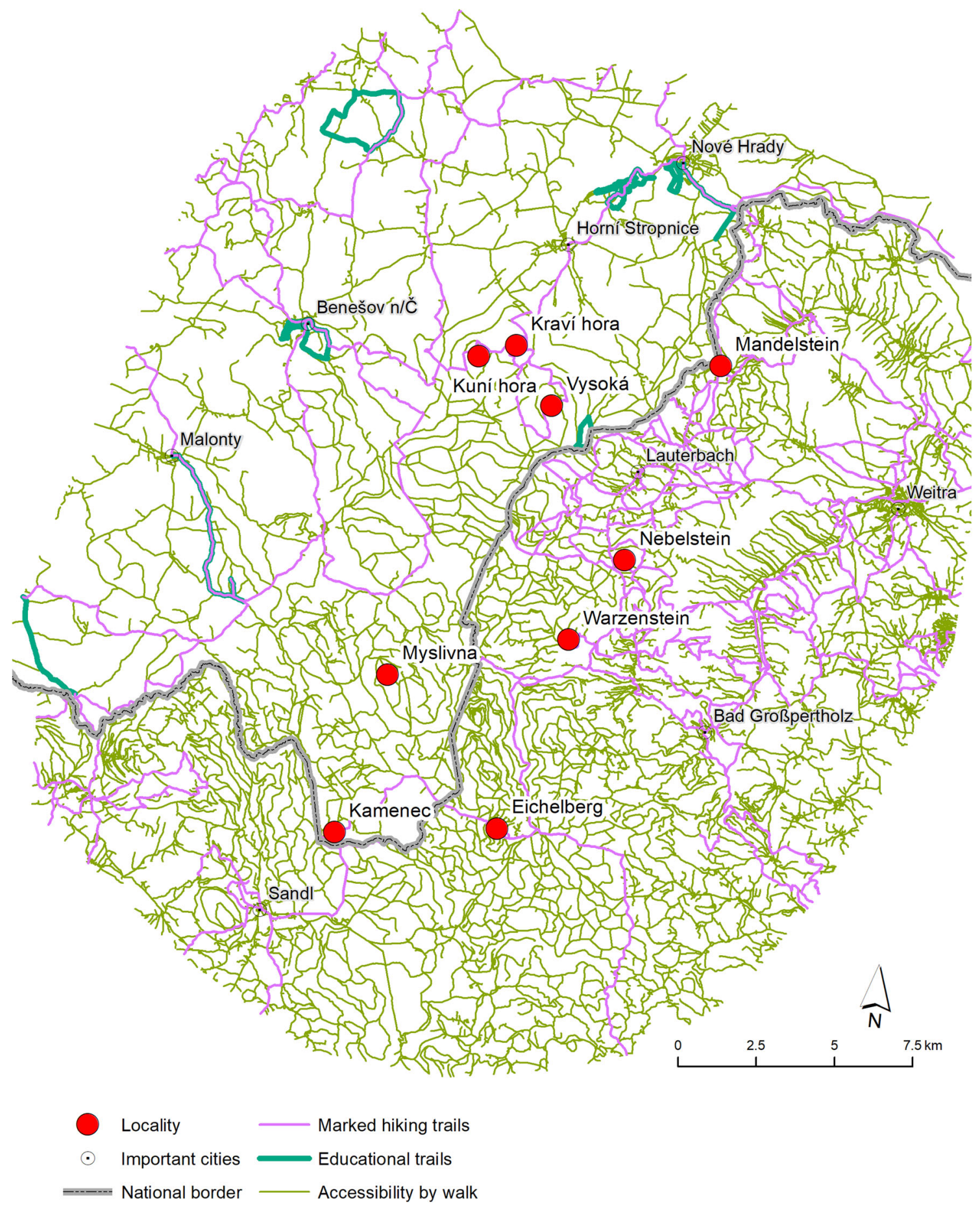

Fig. 5 Accessibility by walk, educational trails and marked hiking trails

the neighbouring Šumava (Bohemian Forest), but there is a number of unmarked paved paths in the area, which were built before 1990s. In addition to the economic accessibility of local forests, these were mainly designed to improve the protection of strictly guarded national borders during the Iron Curtain times (Fig. 3). At present are these paths ideal for hiking and cycling (Fig. 4, Fig. 5). Gratzen Mountains at the Austrian side are extensively interwoven with marked paths in the area of Mt. Nebelstein (Fig. 5), while the southern part around Mt. Eichelberg and Mt. Kamenec has significant lack of official recreational trails (Table 2). Almost all of locations assessed are accessible by foot thru touristic marked trail (Fig. 5). The exception is Mt. Myslivna (nearest marked trail is more than $4 \mathrm{~km}$ far) and partially also Mt. Eichelberg (700 m from nearest trail). Since the locations in assessment are always hilltop locations, it is not so surprising that none of the peaks 
Table 3 Categories of accommodation and number of beds by the distance from geomorphological sites

\begin{tabular}{|c|c|c|c|c|c|c|c|c|}
\hline \multirow{2}{*}{$\begin{array}{l}\text { Study area } \\
\text { distance from the location }\end{array}$} & \multicolumn{4}{|c|}{ Novohradské Mountains and surroundings } & \multicolumn{4}{|c|}{ Gratzen Mountains and surroundings } \\
\hline & Hotel & Guest house & Camp or hostel & Number of beds & Hotel & Guest house & Camp or hostel & Number of beds \\
\hline To $5 \mathrm{~km}$ & 1 & 6 & 1 & 214 & 0 & 4 & 0 & 15 \\
\hline To $10 \mathrm{~km}$ & 2 & 22 & 2 & 816 & 4 & 9 & 0 & 236 \\
\hline To $15 \mathrm{~km}$ & 5 & 30 & 2 & 1129 & 11 & 16 & 0 & 980 \\
\hline
\end{tabular}

can be visited easily with the bike. Most of biking trails are concentrated in valleys where more favourable conditions for this type of recreation are available. None of nine localities is accessible as a part of an educational trail.

The public transport service is not sufficiently covering the area in general and especially during the weekends when one can expect the highest tourist traffic. Only Mt. Eichelberg, Mt. Kraví hora, Mt. Vysoká and Mt. Kuní hora are less than $3 \mathrm{~km}$ from nearest stop served on Saturdays and Sundays (Fig. 3, Table 2); thus, the individual vehicle is crucial for the visits of sites. The Mt. Kamenec is the most difficult location to visit by car with $3.2 \mathrm{~km}$ distance from nearest parking lot.

\section{Accommodation Facilities}

To assess the tourist availability of the nine selected localities, the capacity of accommodation facilities in municipalities was evaluated up to a maximum of $15 \mathrm{~km}$ from each locality (Table 2). In Austria, there were 18 municipalities with an area of $817 \mathrm{~km}^{2}$ and in the Czech area, there were 18 municipalities with a total area of $693 \mathrm{~km}^{2}$ (Fig. 7).

In further analyses, the accommodation capacities in the villages in the Novohradské Mountains and Gratzen Mountains and surroundings (Fig. 7, Table 3) were assessed separately. It is clear from the map of accommodation facilities (Fig. 7) that more accommodation facilities are available in the close vicinity of important geomorphological sites in the Czech area of interest. There are several smaller, mediumsized guest houses and a hotel in the villages of Nové Hrady

Table 4 Number of accommodation facilities in the study area by the number of beds

\begin{tabular}{lll}
\hline Number of beds & Number of facilities CZ & Number of facilities AT \\
\hline $5-19$ & 13 & 15 \\
$20-29$ & 10 & 2 \\
$30-39$ & 6 & 3 \\
$40-49$ & 3 & 1 \\
$50-260$ & 5 & 6 \\
Total & 37 & 27 \\
\hline
\end{tabular}

and Horní Stropnice in the close surroundings of Mt. Kuní hora, Mt. Kraví hora and Mt. Vysoká.

There are 8 accommodation facilities with a capacity of 214 beds within a distance of $5 \mathrm{~km}$ from the sites in the Novohradské Mountains while in the Austrian area of interest, within the same distance only 4 smaller guest houses with a total capacity of 15 beds are located.

There are significantly more accommodation capacities in the Czech part of the territory ( 816 beds compared to 236 beds in Austria - see Table 3) within $10 \mathrm{~km}$ from the geomorphological sites, with guest houses prevailing, which are aimed at supporting hiking, biking, visiting historical monuments and using wellness treatments. There are 9 guest houses and 4 hotels within this distance in Austria, offering wellness, specialties of local cuisine and attractive nearby historic sites.

Within a distance of $15 \mathrm{~km}$ from the geomorphologic sites, there are 2109 beds, of which 1129 are in the Czech and 980 in the Austrian territories. In Austria, there are more hotels that cater to more demanding clients, and in addition to tourism also offer conference and spa services. The largest Hotel SoleFelsen-Bad in Gmünd has a capacity of 260 beds and primarily serves visitors to the thermal salt baths. Other hotels and guest houses in Gmünd are also oriented to spa services. However, during multi-day stays, the potential to visit geomorphologically attractive locations in the Novohradské Mountains and Gratzen Mountains is very high. Guest houses again prevail in the Czech Republic, more oriented towards hikers and cyclists. In addition to visiting naturally attractive localities, however, guests are also interested in nearby historical monuments and urban conservation areas.

Comparing accommodation facilities by size categories, on the Czech side guest houses again predominate, but accommodations include a wider range of bed numbers. On the contrary, in the Austrian part of the territory, accommodation is dominated by either larger hotels with 50 to 260 beds or smaller guest houses with up to 19 beds (Table 4).

\section{Discussion and Conclusion}

The Novohradské Mountains on the Czech side and the Gratzen Mountains on the Austrian side of the state border 


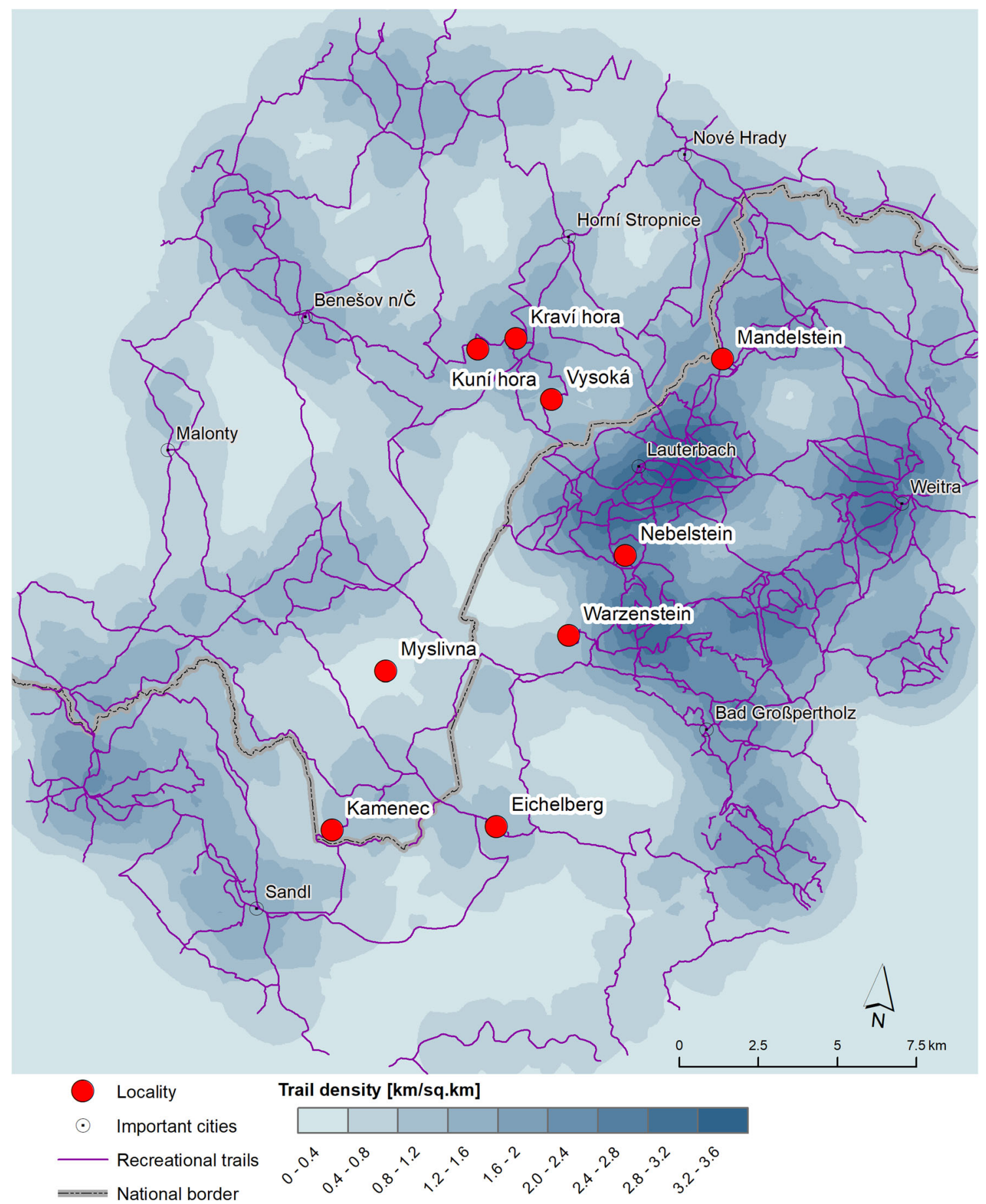

Fig. 6 Density of recreational trails

between the Czech Republic and Austria are located in the area of the so-called Iron Curtain before the Velvet Revolution of 1989 (Rypl et al. 2016). Before 1989, the territory on the Czech side could only be visited by permission and only the personnel of the Czechoslovak People's Army (Rypl et al. 2016) were allowed to enter the territory. Therefore, as expected, the overall density of recreational routes is much higher on the Austrian side than on the Czech side (Fig. 6). Hand in hand with this density of recreational trails, there are fewer possibilities for car and public transport, cycling and hiking on the Czech side than on the Austrian side (Fig. 6). In the inland of the Czech Republic, the density of recreational routes has been significantly higher in similar tourist potential studies (Bajer et al. 2014; Bajer et al. 2018). 


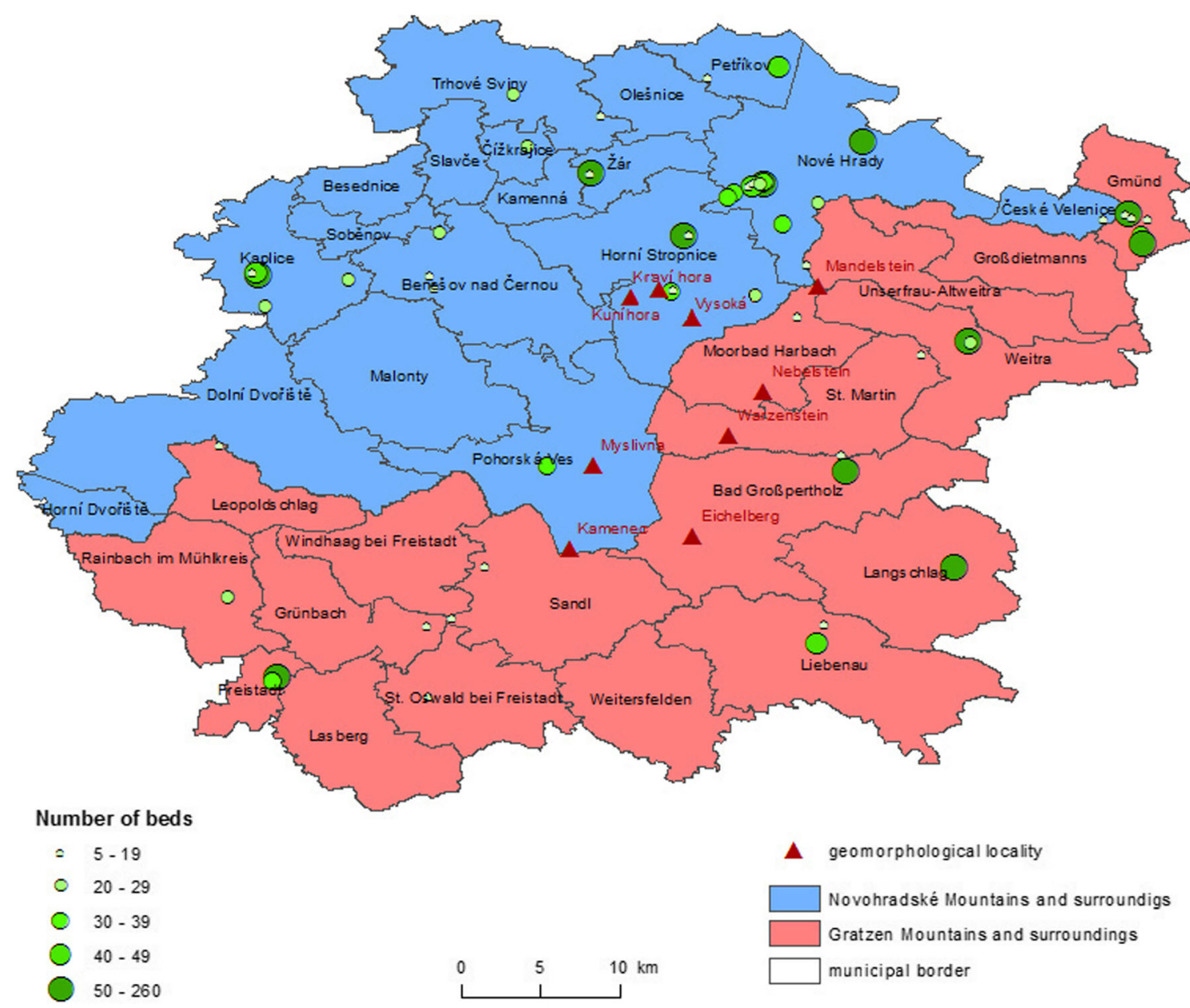

Fig. 7 Location of accommodation facilities and accommodation capacity in study areas

More interesting analyses can be seen in accommodation capacities (Fig. 7). The total number of beds is currently larger on the Czech side of the territory. However, beds on the Czech side are located in smaller facilities, which experienced unprecedented development after 1989 when the possibility of visiting previously unavailable areas appeared (Bajer et al. 2018). The Novohradské Mountains as well as the nearby the Šumava Mountains have become a popular summer destination for Czech citizens and the clientele did not place many demands on accommodation. On the Austrian side of the territory, the larger bed capacity is concentrated in hotel complexes focusing on wellness and balneology, again mainly due to the undisturbed, long-term development of the territory and the greater purchasing power of Austrian citizens.

Another interesting aspect is the difference in the Czech and Austrian sides when comparing the concentration of accommodation capacities at certain distances from geomorphosites. At distances of up to $5 \mathrm{~km}$ and $10 \mathrm{~km}$ of geomorphosites, there are significantly larger accommodation capacities on the Czech side, but within $15 \mathrm{~km}$, the accommodation capacities in both territories are similar. This is due to the fact that geomorphosites in Austria are located in the central, most interesting parts of the mountainous area, far from settlements.

The geomorphosites of Mt. Kraví hora, Mt. Kuní hora and Mt. Vysoká in the Novohradské Mountains are very accessible for hiking, biking, car and public transport, including during the weekend, and a sufficient number of accommodation facilities are available in the close vicinity. At the same time, there is a potential threat of tourists becoming concentrated in protected areas only on the most attractive tourist destinations and routes (Kim et al. 2019; Widawski et al. 2018). Mt. Kamenec and Mt. Myslivna are less accessible by public transport and only one guest house is available in their vicinity. In the Gratzen Mountains, the largest density of recreational trails is reached around Mt. Nebelstein, while the best public transport access is to Mt. Eichelberg. From the point of view of the availability of accommodation, the best options are on the Austrian side of Mt. Nebelstein and Mt. Warzenstein.

The Novohradské Mountains and Gratzen Mountains offer further potential cross-border tourism development, especially in connections between all types of recreational routes. 
However, protection of the territory and preservation of the uniqueness of this area for future generations should be taken into account. The availability of accommodation facilities in a wider area around the geomorphosites, combined with other regional attractions in the area, provides great potential for multi-day stays in the region. A lack of accommodation capacity or poor quality may be one constraint on the tourist development of the area or may limit the number of longer stays in the region (Vijulie et al. 2018). On the Austrian side of the territory, geotourism can be combined, for example with the Golf Club in Weitra, the SPA Sole-Felsen-Bad in Gmünd, visiting the castles in Gmünd and Weitra, and the old towns of Freistadt, Weitra and Gmünd. On the Czech side, there are the castle in Nové Hrady, old towns in Nové Hrady and Trhové Sviny, a monastery in Nové Hrady and fortresses in Cuknštejn and Žumberk.

In conclusion, the geomorphosites of the Novohradské Mountains and the Gratzen Mountains can be presented as a natural attraction in this border region and offered for regular tourist stays, connected with visits to historical towns, castles, monasteries, wellness stays, water recreation, sports activities and cycling. They can contribute to prolonging stays in the region, or interest in getting to know the Czech and Austrian borderlands. In addition to tourism, these locations can also be used for educational school stays and excursions from villages in the vicinity. Specific recommendations for the development of geotourism may include, for example, the construction of educational trails focused on both abiotic nature and biotic nature, or at least for individual landforms, the construction of panels explaining the genesis of individual landforms.

Funding This paper was produced at the Transport Research Centre with the financial support of the Ministry of Education, Youth and Sports within the National Sustainability Programme I, project of Transport R\&DCentre (LO1610) on the research infrastructure acquired from the Operation Programme Research and Development for Innovations (CZ.1.05/2.1.00/03.0064). With the help of institutional support from the Silva Tarouca Research Institute for Landscape and Ornamental Gardening (VUKOZ-IP-00027073) and the paper was so supported by the grant no. 114/2019/S at the University of South Bohemia.

\section{Compliance with Ethical Standards}

Conflict of Interest The authors declare that they have no conflict of interest.

Open Access This article is licensed under a Creative Commons Attribution 4.0 International License, which permits use, sharing, adaptation, distribution and reproduction in any medium or format, as long as you give appropriate credit to the original author(s) and the source, provide a link to the Creative Commons licence, and indicate if changes were made. The images or other third party material in this article are included in the article's Creative Commons licence, unless indicated otherwise in a credit line to the material. If material is not included in the article's Creative Commons licence and your intended use is not permitted by statutory regulation or exceeds the permitted use, you will need to obtain permission directly from the copyright holder. To view a copy of this licence, visit http://creativecommons.org/licenses/by/4.0/.

\section{References}

Al Busaidi Y (2010) Public interpretation of archaeological heritage and archaeotourism: the case study of the Sultanate of Oman; issues and approaches. Lambert Academic Publisher: Saarbrücken. 496 p

Bajer A, Havlíček M, Dostál I (2014) Complex assessment of potential tourist areas tourist potential with emphasis on geotourism - CHKO Žd'árské vrchy. In Fialová J., Pernicová D. (eds.) Public recreation and landscape protection - with man han in hand? Conference proceeding. (pp. 66-74). Mendel University in Brno

Bajer A, Dostál I, Havlíček M (2018) Geotourism and a potential of the tourist industry in Chřriby. In Fialová J. (ed.) Public recreation and landscape protection - with nature hand in hand. Proceeding of Conference, Křtiny, (pp. 192-197). Mendel University Brno

Balatka B, Kalvoda J (2006) Geomorfologické členění reliéfu Čech. Kartografie: Praha. $79 p$

Cháb J, Breitr K, Fatka O, Hladil J, Kalvoda J, Šimůnek Z, Štroch P, Vašíček Z, Zajíc J, Zapletal J (2008) Stručná geologie základu Českého masivu a jeho karbonského a permského pokryvu. Vydavatelství České geologické služby: Praha. 283 p

Chábera S, Huber KH (1999) Beispiele kryogener Verwitterungs - und Abtragungsformen im Eisgarner Granit. Sborník Jihočeského muzea v Českých Budějovicích, Př́rodní vědy 39(1-2):5-17

Culek M (ed) (1996) Biogeografické členění České republiky I. díl. Enigma: Praha. $347 \mathrm{p}$

Czech Statistical Office (2019) Accommodation Establishment Register. Avaliable from: https://vdb.czso.cz/huz/index.jsp

Demek J, Mackovčin P (eds) et al (2014) Zeměpisný lexikon ČR: Hory a nížiny. Lesnická a dřevařská fakulta, Mendelova univerzita v Brně: Brno. $610 \mathrm{p}$

Dowling RK (2011) Geotourism's global growth. Geoheritage 3(1):1-13. https://doi.org/10.1007/s12371-010-0024-7

Dowling RK, Newsome D (eds) (2018) Handbook of geotourism. Edward Elgar Publishing, Cheltenham, p 520

Evans GB, Cleal JCH, Thomas AB (2018) Geotourism in an industrial setting: the South Wales Coalfield Geoheritage Network. Geoheritage 10(1):93-107. https://doi.org/10.1007/s12371-0170226-3

Fleetwood S (1995) Collection of tourism expenditure statistics 1995. World Tourism Organisation: Madrid

Gray M (2013) Geodiversity: valuing and conserving abiotic nature, 2nd edn. Wiley Blackwell, Chichester, p 495

Heřmánek R and Matějka D (1998) Granites of the Novohradské hory Mts. and surrounding area. Acta Universitatis Carolinae Geologica, $42,262-263$

Honey M (2008) Ecotourism and sustainable development: who owns paradise? Washington DC: Island Press

Honțuş AC, Dinu TA, Beciu S (2015) Tourism sustainable development in the centre region of Romania. Proceedings of the 25 th International Business Information Management Association Conference - Innovation Vision 2020: From Regional Development Sustainability to Global Economic Growth. (pp. 2137-2145). IBIMA

Hose TA (2005) Geo-tourism - appreciating the deep side of landscapes. In: Novelli M (ed) Niche tourism: contemporary issues, trends and cases. Elsevier, Oxford, pp 27-37

Hose TA (2008) Towards a history of geotourism: definitions, antecedents and the future. In: Burek CV, Prosser CD (eds) The history of geoconservation. Geological Society, London, pp 37-60 
Huber KH (1999) Zum Formenchatz der Granitverwitterung und abtragung im nordwestlichen Waldviertel. In Steininger FF. (ed.), Erdgeschichte des Waldviertels. Waldviertler Heimatbund. (pp. 113-132). Horn: Austria

Kim Y, Kim CK, Lee DK, Lee HW, Andrada RIT (2019) Quantifying nature-based tourism in protected areas in developing countries by using social big data. Tour Manag 72:249-256. https://doi.org/10. 1016/j.tourman.2018.12.005

Kubalíková L (2013) Geomorphosite assessment for geotourism purposes. Czech J Tourism 2(2):80-104. https://doi.org/10.2478/cjot2013-0005

Kubalíková L (2018) Czech Republic: the planning and management of geotourism's hidden resources. In: Dowling RK, Newsome D (eds) Handbook of Geotourism. Edward Elgar Publishing, Cheltenham, pp 417-432

Michniewicz A (2019) Tors in Central European Mountains -are they indicators of past environments? Bulletin of Geography. Physical Geography Series. 16(1):67-87. https://doi.org/10.2478/bgeo2019-0005

Migoń P, Migoń EP (2017) Viewpoint geosites - values, conservation and management issues. Proc Geol Assoc 128(4):511-522. https:// doi.org/10.1016/j.pgeola.2017.05.007

Migoń P, Różycka M, Michniewicz A (2018) Conservation and geotourism perspectives at granite geoheritage sites of Waldviertel, Austria. Geoheritage 10(1):11-21. https://doi.org/10.1007/s12371017-0219-2

Natura 2000 Network Viewer (2019) Avaliable from http://natura2000. eea.europa.eu/

Naturpark Nordwald Grosspertholz (2019) Avaliable from https://www. naturparke.at/naturparke/niederoesterreich/naturpark-nordwaldgrosspertholz/

Němeček J, Rohošková M, Macků J, Vokoun J, Vavříček D, Novák P (2001) Taxonomický klasifikační systém půd České republiky. Česká zemědělská univerzita. Praha

Pavlíček V (2004) Geologie Novohradských hor. In Kubeš J (ed.) Krajina Novohradských hor - fyzicko-geografické složky krajiny (pp. 9 45). České Budějovice: Jihočeská univerzita Pedagogická fakulta

Ramm F (2017) OpenStreetMap Data in Layered GIS Format. Available from https://download.geofabrik.de/osm-data-in-gis-formats-free. pdf

Reynard E, Holzmann C, Guex D (2003) Geomorphologie et tourisme: quelles relations? In: Reynard E, Holzmann C, Guex D, Summermatter N (eds) Geomorphologie et tourisme, Actes de la Reunionannuelle de la Societe Suisse de Geomorphologie (SSGm), Travaux et Recherches $n^{\circ} 24$, Finhaut, 21-23septembre 2001. Institut de Geographie, Lausanne, pp 1-10
Rypl J, Kirchner K (2017) Scientific values of landforms as the basis for the declaration of protected sites (a case study of Mt. Kraví hora in the Novohradské hory Mts., Czech Republic). Appl Ecol Environ Res 15(3):1537-1550. https://doi.org/10.15666/aeer/1503 15371550

Rypl J, Kirchner K, Dvořáčková S (2014) Geomorphological inventory of rock landforms on Mt. Kamenecin the Novohradské hory Mts. (the Czech Republic). Carpathian J Earth Environ Sci 9(3):253-260

Rypl J, Kirchner K, Dvoř́ǎková S (2016) Geomorphological inventory as a tool for proclaiming geomorphosite (a case study of Mt. Myslivna in the Novohradské hory Mts. - Czech Republic). Geoheritage 8(4):393-400. https://doi.org/10.1007/s12371-0150169-5

Rypl J, Kirchner K, Blažek M (2017) The spatial distribution of rock landforms in the Pohořská Mountains (Pohořská hornatina) Czech Republic. Acta Geographica Slovenica 57(2):45-55. https:// doi.org/10.3986/AGS.1184

Rypl J, Kirchner K, Ryplová R (2019) Contribution to the assessment of geomorphosites in the Czech Republic (a case study of the northeastern part of the Novohradské Mountains). Geoheritage 11(2): 427-439. https://doi.org/10.1007/s12371-018-0293-0

Rypl J, Kirchner K, Kubalíková L, Divíšek J (2020) Geological and geomorphological conditions supporting the diversity of rock landforms in the Pohořská Mountains (South Bohemia, Czech Republic). Geoheritage 12(1):2. https://doi.org/10.1007/ s12371-020-00430-1

Šefrna L (2004) Půdy Novohradských hor. In Kubeš J (ed.) Krajina Novohradských hor - fyzicko-geografické složky krajiny. (pp. 46 - 55). České Budějovice. Jihočeská univerzita Pedagogická fakulta

Tolasz R, Baštýřová H (2007) Atlas podnebí Česka. Český hydrometeorologický ústav, Praha, $255 \mathrm{p}$

Vijulie I, Matei E, Preda M, Manea G, Cuculici R, Mareci A (2018) Tourism-a viable alternative for the development of rural mountainous communities. case study: Eftimie murgu, caras-severin county, Romania. GeoJ Tour Geosites 22(2):419-431. https://doi.org/10. 30892/gtg.22212-299

Weber K, Duyster J (1990) Moldanubian Zone of the Waldviertel, Lower Austria. In International Conference on Paleozoic Orogens in Central Europe. (pp. 99-114). Göttingen

Widawski K, Jary Z, Oleniewicz P, Owczarek P, Markiewicz-Patkowska J, Zar ba A (2018) Attractiveness of protected areas for geotourism purposes from the perspective of visitors: The example of Babiogórski National Park (Poland). Open Geosci 10(1):358-366. https://doi.org/10.1515/geo-2018-0028 